\title{
Pengaruh Penggunaan Berbagai Jenis Ikan sebagai Inang terhadal Kelangsungan Hidup Glochidia Kijing Taiwan (Anodonta woodiana Lea)
}

\author{
The Glochidia (Anodonta woodiana Lea) Viability on Host Fish
}

\author{
Afreni Hamidah \\ Jurusan Biologi, FMIPA Universitas Sriwijaya, Jl. Kampus Unsri Km 32 Inderalaya \\ Kabupaten Ogan Ilir Sumetera Selatan. Telp.0711-580772Ｅ-mail: afreni_unsri@yahoo.com
}

\begin{abstract}
The research about the glochidia Anodonta woodiana Lea viability on host fishes has been conducted in the Laboratory of Zoology Biology Department Mathematic and Science Faculty Sriwijaya University from July - November 2004. The research applied completely randomized design with 5 treatments of host fish (Cyprinus carpio, Pristolepis fasciatus, Oreochromis niloticus, Trichogaster pectoralis and Clarias gariepinus) with 6 replications. The results of the research showed that the use of fishes host has influenced the glochidia viability. The highest glochidia viability was in Trichogaster pectoralis there was a great diffoence compared to other host fish. This result showed that Trichogaster pectoralis was the most effective host fish of Anodonta woodiana glochidia.
\end{abstract}

Key word: Glochidia, mussel, host fishes

Diterima: 08 September 2005, disetujui: 14 Juni 2006

\section{Pendahuluan}

Kijing Taiwan (Anodonta woodiana Lea) merupakan salah satu jenis kerang air tawar dari famili Unionidae, termasuk ke dalam kelas Pelecypoda atau Bivalvia, filum Moluska. Kijing Taiwan pertama kali ditemukan di Indonesia pada tahun 1971 di Balai Penelitian Perikanan Darat Cibalagung, Bogor. Kijing Taiwan bukan berasal dari Indonesia, kedatangannya ke Indonesia tanpa sengaja ikut terbawa saat Indonesia mengimpor ikan nila (Tilapia nilotica) dari Taiwan (Djajasasmita, 1982).

Kijing Taiwan memiliki potensi ekonomis yang besar karena sudah lama dikenal penduduk dan biasa dikonsumsi sebagai salah satu bahan pangan sumber protein hewani. Berdasarkan penelitian Anwar (1980), daging kijing memiliki kandungan protein sebesar $5,67-7,37 \%$ per 100 gram daging dan kandungan zat besi 31,2 - 35,85 $\mathrm{mg} / 100$ gr daging. Selain itu, kijing ini juga digunakan sebagai bahan pakan ternak, industr kancing, dan penghasil mutiara air tawar sert untuk keperluan pengobatan (Suwignyo et al 1982). Selain itu, Kijing Taiwan jug mempunyai nilai ekologis dalam mengurang pencemaran lingkungan karena dapa digunakan mengurangi logam berat (Hasim 2003; Korlak \& Bogaslaw, 2001) da mengurangi phytoplankton (Wu et al., 2005)

Di beberapa sungai di Sumatera Selata telah terjadi penurunan kelimpahan populas kijing Taiwan secara nyata, sehingga kijin Taiwan ini sulit didapat dan hanya dijumpa pada daerah dan sungai tertentu. Penuruna: kelimpahan populasi ini disebabkan ole kegiatan eksploitasi, diantaranya akiba pemanenan yang terus-menerus berlangsun sampai sekarang tanpa ada upaya budidaya da perubahan kualitas perairan sungai tersebu yang tidak mendukung bagi kehidupan kijin Taiwan.

Faktor lain yang menyebabka penurunan kelimpahan kijing Taiwan adala 
rendahnya produksi 'spat' (stadium awal) sebagai akibat dari tingkat mortalitas yang tinggi. Menurut Suwignyo et al., (1982), meskipun fekunditas induk kijing Taiwan cukup besar yaitu 31.700 - 371.000 individu glochidia dalam sekali berbiak namun mortalitasnya sangat tinggi, dan hanya $0,001-$ $0,005 \%$ saja yang berhasil berkembang menjadi dewasa, sedangkan selebihnya akan mati. Hal ini dikarenakan cara berkembang biak kijing Taiwan tersebut, sebelum menjadi kijing Taiwan yang sempurna, membutuhkan induk semang atau inang untuk pertumbuhannya. Inang yang dipilih menjadi induk semangnya adalah ikan. Tiap jenis kijing mempunyai satu atau beberapa jenis ikan sebagai induk semangnya (Djajasasmita, 1982). Menurut (Rheichard et al., (2006) Ikan kelompok Cyprinidae merupakan inang yang baik bagi kijing Taiwan memiliki hubungan simbiosis mutualisma.

Di dalam tubuh inang, organ-organ internalnya akan berkembang sampai akhirnya mereka melepaskan diri dan memulai hidup baru dan bebas sebagai benthos (Thorp and Covich, 1991). Andaikan glochidia ini mampu menyempurnakan dirinya menjadi anak kijing taiwan, namun karena ukurannya yang kecil (0,1-0,4 mm) dan sifatnya yang bentik maka ia merupakan makanan empuk hewan air lainnya (Kashyap, 1997).

Berdasarkan hasi penelitian Suwignyo et al., (1984), periode parasit glochidia kijing Taiwan berlangsung selama 8,4 - 14,4 hari. Lama waktu periode parasit ini tergantung pada jenis ikan inang. Jenis ikan inang yang digunakan antara lain ikan beunteur, koki, koan dan seribu akan tetapi kelangsungan hidup glochidia menjadi anak kijing tidak dihasilkan. Ketiadaan kelangsungan hidup yang dihasilkan ini dipengaruhi olah banyak faktor antara lain ketersediaan nutrisi, faktor fisik kimia air yang tidak memenuhi syarat hidup sebagai kesesuaian habitatnya ataupun faktor lainnya.

Kelangsungan hidup glochidia tergantung pada jenis ikan sebagai inang. Salah satu faktor yang penting untuk menentukan perkembangan reproduksi glochidia ini adalah ikan sebagai inang tempat glochidia tersebut menempel. Bila tidak mendapat ikan yang tepat sebagai inang, maka glochidia tersebut akan mati. Sehubungan dengan hal tersebut, maka dilakukan penelitian mengenai kelangsungan hidup glochidia kijing Taiwan pada beberapa jenis ikan sebagai inang untuk memperoleh jenis ikan yang cocok digunakan sebagai inang. Dengan diketahuinya jenis inang yang cocok bagi glochidia dapat menjamin dan meningkatkan taraf hidup dan keberhasilan glochidia berkembang menjadi anak kijing Taiwan.

\section{Metode Penelitian}

\section{Bahan}

Bahan yang digunakan adalah induk Kijing Taiwan yang gonadnya telah matang berukuran kurang lebih $15-16 \mathrm{~cm}$, lima jenis ikan sebagai inang yaitu ikan mas, sepatung, nila,dan sepat masing-masing berukuran 4,5$4,7 \mathrm{~cm}$ serta ikan lele berukuran $6,0-6,5 \mathrm{~cm}$. Kelima jenis ikan dipilih berdasarkan kebiasaan hidupnya, yang menempati dasar perairan, di tengah dan di permukaan air. Selain itu digunakan pellet sebagai makanan kijing dan ikan.

Peralatan yang digunakan adalah sembilan akuarium berukuran $60 \times 50 \times 50 \mathrm{~cm}^{3}$ sebagai akuarium penyemburan dan 36 akuarium pengamatan berukuran $30 \times 50 \times 50$ $\mathrm{cm}^{3}$, bak teraso berukuran $100 \times 50 \times 50 \mathrm{~cm}^{3}$ sebagai tempat menampung induk kijing yang telah diseleksi, aerator, mikroskop, lup, gelas ukur, jangka sorong calliper, hand counter, pinset, pipet tetes, thermometer, kertas $\mathrm{pH}$ indicator, DO meter, plankton net, sedwigk rafter counting cell, kertas milimeter, ember, baki, jaring kasa plastik dan botol sampel.

\section{Rancangan Percobaan}

Rancangan Percobaan yang digunakan dalam penelitian ini adalah Rancangan Acak Lengkap dengan 5 perlakuan variasi jenis ikan inang yaitu ikan mas (Cyprinus carpio), sepatung (Pristolepis fasciatus), nila (Oreochromis niloticus), sepat (Trichogaster pectoralis) dan lele (Clarias gariepinus), Masing-masing perlakuan diulang sebanyak 6 kali. 


\section{Cara Kerja}

Terlebih dahulu dipersiapkan 6 buah akuarium berukuran $60 \times 50 \times 50 \mathrm{~cm}^{3}$ sebagai akuarium penyemburan dan 30 akuarium pengamatan berukuran 30 x 50 x $50 \mathrm{~cm}^{3}$. Keseluruhan akuarium diisi air sampai ketinggian $25 \mathrm{~cm}$ dari dasar dan diaerasi secara terus menerus. Di dalamnya dimasukkan masing-masing seekor induk kijing Taiwan yang telah matang gonad dan telah diseleksi sebelumnya dan 5 jenis ikan inang, masingmasing 3 ekor tiap jenisnya. Setelah 48 jam terjadi penyemburan atau pengeluaran larva glochidia dari induk kijing Taiwan yang kemudian akan menempel di sirip ikan inang. Ikan inang dipindahkan ke dalam akuarium pengamatan menurut jenis dan asal akuarium penyemburan. Dengan demikian tiap akuarium pengamatan berisi tiga ekor ikan dari jenis, ukuran dan berasal dari akuarium penyemburan yang sama, yang merupakan satu unit pengamatan.

Setelah periode parasit berakhir, ikan inang dipindahkan dari akuarium pengamatan. Akuarium tersebut dibiarkan selama 60 hari untuk memberi kesempatan bagi kijing muda berkembang. Anak kijing yang didapatkan berukuran 0,1-0,2 mm. Selama pemeliharaan, kijing muda diberi makan berupa pelet halus. Setelah 60 hari, air akuarium dibuang dan diamati jumlah anak kijing yang mampu hidup dari masing-masing jenis ikan inang. Semua air disaring dengan menggunakan plankton net dan hasilnya diamati dengan kaca pembesar dan mikroskop binokuler. Tingkat kelangsungan hidup diketahui dengan cara menghitung persentase banyaknya anak kijing yang mampu hidup dibagi jumlah keseluruhan glochidia yang menempel pada masing-masing jenis ikan inang.

\section{Analisis Data}

Data yang didapat dari hasil pengamata dianalisis variansinya menggunakan ANOV satu arah dan dilanjutkan dengan uji $\mathrm{BN}^{\top}$. (Beda Nyata Terkecil) pada taraf kepercayaa $\alpha: 0,5$, jika terdapat perbedaan yang nyata.

\section{Hasil dan Pembahasan}

Berdasarkan penelitian yang telal dilakukan maka didapatkan kelangsunga hidup kijing Taiwan yang sangat kecil (Tabe 1). Kelangsungan hidup yang didapatka berkisar antara $0,184 \% \quad-\quad 1,456 \%$ Kelangsungan hidup yang tertinggi terdapa pada ikan sepat, sedangkan yang terendal terdapat pada ikan lele. Dari hal ini berart bahwa penerimaan berbagai jenis ikan inan menunjukkan hasil yang berbeda-bed terhadap persentase kelangsungan hidup yan merupakan gambaran keberhasila transformasi glochidia menjadi juvenil.

Berdasarkan hasil uji BNT rata-rat persentase tingkat kelangsunan hidup glochidi yang dihasilkan pada ikan sepat menunjukka perbedaan yang nyata dibandingkan denga ikan lainnya. Hasil ini menunjukka keberhasilan trasformasi glochidia menjad anak kijing yang lebih tinggi dibandingka dengan hasil penelitian yang didapatkan ole Suwingyo et al., (1984). Berdasarkan hasi penelitian Suwignyo et al., (1984) kelangsungan hidup glochidia menjadi ana kijing tidak dihasilkan sama sekali denga periode parasit glochidia kijing Taiwan sekita $8,4-14,4$ hari. Jenis ikan inang yang digunaka antara lain ikan beunteur, koki, koan da seribu. Hasil ini menunjukkan tingka kelangsungan hidup glochidia menjadi ana kijing sangat dipengaruhi oleh jenis da tingkat kekebalan ikan inang.

Tabel 1. Persentase (\%) kelangsungan hidup glochidia kijing Taiwan pada berbagai jenis ikan

\begin{tabular}{lccccc}
\hline \hline & \multicolumn{5}{c}{ Jenis ikan } \\
\cline { 2 - 6 } & Lele & Mas & Sepatung & Nila & Sepat \\
\hline \hline Rata-rata & $0^{\mathrm{a}}$ & $0,031 \pm 0,024^{\mathrm{a}}$ & $0,046 \pm 0,011^{\mathrm{a}}$ & $0,055 \pm 0,033^{\mathrm{a}}$ & $0,243 \pm 0,265^{\mathrm{b}}$
\end{tabular}

Keterangan : Angka yang diikuti dengan notasi yang berbeda menunjukkan perbedaan yang nyata pada taraf $\alpha$ 0,05 
Ikan sepat merupakan ikan yang lebih cocok dan efektif digunakan sebagai inang dibandingkan ikan lele, ikan mas dan ikan sepatung. Hal ini berkaitan erat dengan tingkat kekebalan ikan sepat tersebut yang paling rendah dibandingkan dengan ikan mas, lele, nila dan sepatung yang digunakan dalam penelitian. Penelitian ini mirip dengan penelitian Reichard et al., (2006) yang membandingkan berbagai jenis ikan air tawar Eropa, dan paling cocok sebagai inang adalah ikan dari keluarga Cyprinidae.

Hasil penelitian Nursanti (1995), menunjukkan bahwa jumlah glochidia yang berhasil ditransformasikan oleh satu jenis ikan dapat digunakan untuk menentukan keefektifan ikan sebagai inang. Ikan sepat memiliki jumlah glochidia yang berhasil menjadi juvenil paling tinggi bila dibandingkan dengan ikan lainnya.

Pada ikan sepat yang mempunyai kekebalan yang kurang tahan terhadap penempelan glochidia, maka glochidia akan dibungkus oleh lapisan lendir dan epitel inangnya kemudian membentuk kista pada bagian tubuh inangnya. Selama periode penempelan ini, glochidia memperoleh makanan dari jaringan tubuh ikan sepat dengan bantuan sel pagositik yang terdapat pada mantel larvanya. Setelah periode penempelan ini selesai glochidia akan lepas dari tubuh ikan sepat dan mulai hidup bebas sebagai benthos (Barnes 1963 dalam Suwignyo et al., 1984 ). Rheicard et al., (2006) pada hubungan simbioses mutulisma antara ikan dengan kijing, ikan dimanfaatkan untuk media tumbuh glochidia kijing yang bersifat parasit obligat, sedangkan ikan meletakkan telurnya di insang kijing sampai menetas menjadi larva bebas.

Jumlah glochidia yang mati dan tidak berhasil menjadi juvenil paling banyak terdapat pada ikan lele karena tidak ada satupun dari glochidia yang berhasil menjadi anak kijing (juvenil), meskipun pada awal infeksi lebih banyak glochidia yang menempel. Hal ini disebabkan penolakan ikan lele yang lebih banyak terhadap penempelan glochidia, sehingga banyak glochidia yang lepas dari tubuh ikan inang tersebut.

Menurut Kat (1984), inang yang tidak cocok akan menolak glochidia setelah proses pengkistaan, adapun waktu pengkistaan berlangsung 2 - 36 jam setelah penempelan. Ada beberapa faktor yang menyebabkan glochidia menjadi rusak atau mati, yaitu akibat proses hitolisis (meleburnya sel terutama akibat rusaknya sel inang) dan invasi (bergeraknya sumber infeksi pada inang dan berkembang di dalam tubuh inang) oleh sel inang, sehingga glochidia akan jatuh prematur kira - kira 2 hari setelah penempelan, jika suhu di atas $33^{\circ} \mathrm{C}$ glochidia menjadi rusak dan cepat lepas dari inang (Dudgeon and Morton, 1983).

\section{Kesimpulan}

Berdasarkan penelitian yang telah dilakukan, maka dapat diambil kesimpulan bahwa penggunaan berbagai jenis ikan inang memberikan pengaruh yang nyata terhadap kelangsungan hidup glochidia kijing Taiwan. Kelangsungan hidup glochidia yang tertinggi pada ikan sepat.

\section{Daftar Pustaka}

Anwar, S. 1980. Pengamatan Pertumbuhan Kijing Air Tawar (Famili Unionidae) pada Kolam Percobaan Laboratorium Fakultas Perikanan Universitas Lambung Mangkurat. Proyek Peningkatan/Pengembangan Perguruan Tinggi Universitas Lambung Mangkurat (No. Proyek 02-2-2-0) Tahun Anggaran 1980/1981.

Djajasasmita, M. 1982. Bagaimana Kijing Taiwan (Anodonta woodiana Lea) dapat Menyusup ke Indonesia? Buletin Kebun Raya. I: 4-8.

Dudgeon, D. and Morton, B. 1983. Site Selection and attachment duration of Anadonta woodiana (Bivalvia: Unionacea) glochidia on fish hosts. The Zoological Society of London. 204: 355362.

Hasim, 2003. Kerang Sebagai Biofilter Logam Berat. Harian Kompas, 23 september 2003

Kashyap, V. 1997. Life of Invertebrates. Second Revised Edition. Vikas Publishing House PVT LTD. New Delhi.

Korlak E. and Bogaslaw Z., 2001. The Bioaccumulation of Heavy Metals By The Mussel Anodonta Woodiana (LEA, 1834) and Dreissena polymorpha (PALL.) In The Heated Konin Lakes. Arch. of Polish Fisheries. 9(2): 229237

Kat, P.W. 1984. Parasitisme and The Unionaceae (Bivalvia). Biol Rev: 189 - 207. 


\section{Afreni Hamidah}

Nursanti, I. 1995. Penentuan Beberapa Jenis dan Ukuran Ikan yang Paling Efektif Sebagai Inang Bagi Larva Kijing Taiwan (Anodonta woodiana, Lea). Skripsi. Fakultas MIPA. Institut Pertanian Bogor.

Rheichard, M., Ondrachora, M., Przbylski, M., Linsx, H., and Smith, C. 2006. The cost and benefith in an unusual symbiosis: Experimental evidence that Bitterly fish (Rhodeus sericeus) are parasites of unionid mussels in Europe. J.of Evolutionairy 19 (3) : 788-797.

Suwignyo, S., Basmi, J., Batu, D.T.F.L. dan Affandi, R. 1982. Studi Biologi Kijing Taiwan (Anodonta woodiana, Lea). Buletin Penelitian. 3: 9-13
Suwignyo, P., Suwignyo, S. dan Suwardi, K. 198 Organisme Inang Glochidia Kijing Taiwar Laporan Penelitian. Fakultas Perikanan IPE Bogor.

Thorp, H.J. and Covich, A.P. 1991. Ecology an Classification of North American Freshwate Invertebrates. Academic Press Inc. USA.

Wu, Q., Chen, Y. and Liu, Z. 2005. Filtering Capacity c Anodonta woodiana and Its feedin selectivity on phytoplankton. PubMed 16(12) 2423-7 